\title{
Maqashid Al-Syari'ah (Tujuan-Tujuan Hukum Islam) Sebagai Pondasi Dasar Pengembangan Hukum
}

\author{
Oleh : \\ Muhyidin,M.Ag, M.H \\ Fakultas Hukum Bagian Perdata Universitas Diponegoro \\ arfi27@gmail.com
}

\begin{abstract}
Abstaksi
Konsepsi Syatibi tentang maqasid al-syari'ah (tujuan hukum Islam) mempunyai keistimewaan dan keunikan tersendiri yang membuatnya berbeda dengan para pendahulunya. Syatibi melihat, pada satu sisi adanya keterpaduan dan kesatuan kehendak Tuhan dalam menciptakan alam semesta. Konsep ini melahirkan suatu pandangan tentang kesatuan syari'ah yang berarti bahwa semua hukum berasal dari satu sumber yang oleh karena itu mustahil berbeda.Konsep kemaslahatan ini menuntut adanya pertimbagan maslahah dan mafsadah. Pertimbangan ini mengimplikasikan hubungan yang sangat signifikan antara hukum syari'ah dengan kondisi umat manusia. Hubungan ini pada gilirannya menimbulkan adannya aturan-aturan hukum yang beragam dan berbeda.
\end{abstract}

Kata kunci : Syatibi, Maqashid al-Syari'ah, kemaslahatan, aturan hukum 


\section{A. Latar Belakang Masalah}

Shahratsani menyatakan bahwa peristiwa yang dihadapi manusia tidak dapat dihitung dan tak terhingga, maka tidak masuk akal bila dalam setiap peristiwa telah tersedia keterangan (nash) yang tegas. Dan jika keterangan itu terbatas sedangkan peristiwanya tidak terbatas, atau jika yang tak terbatas tidak dapat ditetapkan oleh yang terbatas dapatlah dipastikan bahwa ijtihad harus diterima, sehingga tidak ada satupun peristiwa tanpa ijtihad. ${ }^{1}$

Mungkinkah tantangan-tantangan baru yang tak terbatas dan terus-menerus berubah dihadapi dengan konsepsi shari'ah (hukum islam) yang tetap da tak berubah? Jawaban atas pertanyaan ini antara lain diberikan oleh Sayyid Qutb sebagai berikut. Rincian dan penerapan shari'ah yang dibutuhkan manusia untuk menampung kebutuhan-kebutuhan kontemporer tidak keluar dari empat kemungkinan, Pertama; shari'ah telah menetapkan suatu hukum tertentu dengan teks yang jelas dan tegas (qat'iy al-dilalah). Dalam kaitan ini penenuan hukum harus ditetapkan menurut "huruf"nya secara benar tanpa perubahan atau penyimpangan sedikitpun. Ketekntuan yang ketat ini terutama yang menyangkut materi hukum yang mengatur sendi-sendi kehidupan masyarakat, seperti kahidupan hukum tentang riba yang secara principal bertentangan dengan kaidah social ekonomi yang berdemensi kemanusiaan. Kedua; Shari'ah menetapkan hukum dengan teks yang bersifat ambigus yakni teks yang petunjuk hukumnya tidak jelas (zannity al-dilalah) sehingga terbuka kemungkinan untuk ijtihad. Ketika; shari'ah menetapkan hukum secara umum tentang suatu masalah.

\footnotetext{
${ }^{1}$ Shahratsani, al-Milal wa al-Mihlm., Bairut;Dar al-Fikr, t.t., hlm. 200.
} 
Ketentuan semacam ini juga menjadi salah satu medan ijtihad. Dan ke empat; shari'ah tidak menyinggung masalah tertentu dengan ketentuan khusus maka terbuka lebar pintu ijtihad, misalnya melakukan deduksi analogis (qiyas). ${ }^{2}$

Di sini terletak fleksibelitas shari'ah Islam yang sebagian besar tampil dengan prinsipprinsip yang global dan umum, sehingga dibawah naungannya terpancar beragam bentuk masyarakat yang aktif bergerak dan berubah dalam lingkarannya yang amat luas. Untuk tujuan hidup dan kemanusiaan ini maka dicarilah semangat dari shari'ah sebagai dimensi etis al-Qur'an dan Sunnah oleh pelaku-pelaku ijtihad terdahulu.

Adalah Umar bin Khattab dalam beberapa kasus menunjukkan kepiawaian ijtihad yang sangat tajam visinnya dalam pencarian tujuan huum. Umar menolak memberikan zakat kepada muallaf ${ }^{3}$ yang secara tegas ditetapkan oleh al-Qur'an Surat al-Taubah ayat 60 karena ia menganggap bahwa sifat muallaf adalah sifat yang tidak tetap, sehingga suatu saat bila sifat itu sudah tidak ada maka dialihkan kepada orang lain yang lebih berhak. ${ }^{4}$ Sikap dan tindakan tersebut, menurut Ahmad Amin, membuktikan kepada kita bahwa ia tidak hanya sekedar mengunakan ratio ( $\left.r a^{\prime} y u\right)$ dalam menetapkan hukum bagi peristiwa yang tidak ada nasnnya, akan tetapi lebih jauh ia berusaha menenukan maslahah yang menjadi tujuan dishari'atkannya sesuatu hukum. ${ }^{5}$

Para ulama ushul fiqh dipelopori oleh Shafi'i telah bangkit dan berusaha menggali sumber-sumber hukum yudisprudensi selain al-Qur'an dan Sunnah. Kurang lebih mereka sepakat bahwa qiyas merupakan metode penentuan hukum yang terpenting. Menurut

\footnotetext{
${ }^{2}$ Sayyib Qutb, al-Muslimin, Kairo: Dar al Misriyyah, t.t., alih bahasa Mu’ti Nurdin, Masyarakat Islam, Jakarta Rajawali Press, 1985, hlm.. 41-43.

3 Muallaf pengertiannya adalah orang yang dilemahkan yakni lemah dalam keimanan. Namun pengertian itu para ulama' membagi dalam beberapa hlm. yang semuannya bertujuan agar para muallaf masuk dan atau memperkuat keimanannya.

4 M. Saud Ramdan al-Buti, Dawabit al-Maslahah, Bairut: Muassasah al-Risalah, 1986, hlm.. 140-151, lihat juga Ibnu Rusyd, Bidayah al-Mujtahid, Dar al-Fikr, t.t. hlm..333.

${ }^{5}$ Ahmad Amin, Fajr al-Islam, Kairo: Maktabah al-Nahdiah al-Misriyah, 1975, hlm..238.
} 
mereka,ketika menetapkan suatu hukum Allah menghendaki suatu tujuan danhikmah tertentu. Maka seandainya dua peristiwa mempunyai aspek determinan yang serupa dan salah satunnya terdapat nas yang tegas, dapatlah kita menetapkan hukum (nas) itu kepada peristiwa lainnya. Sungguhpun demikian, deduktif analogis yang parsial dan individual ini dalam perkembangannya justru sulit menemukan tujuan shari'ah yang besendikan maslahah.

Sementara itu di Andalusia, tampil tokoh Ibnu Hazm yang mengembangkan tradisi pemikiran zahiri (tekstualis) yang cenderung ekstrim. Sungguhpun aliran utama tradisi fiqh yang berkembang di Andalusia adalah mazhab Maliki akan tetapi warisan intelektual Ibnu Hazm tidak bisa dianggap kecil. Dialah yang secara sistematis menulis karya besar dalam ushul fiqh (al-ihkam fi Ushul al-Ahkam) dan fiqh (al-Muhalla) yang banyak mendapat pujian ulama fiqh antara lain Ibnu Qudamah dan Syekh'Izzudin bin Abdu al-Salam al-Dimashqi.

Dengan latar belakang intelektual yang punya ciri khas tersendiri maka muncullah seorang ulama bernama Abu Ishaq al-Shatibi (selanjutnya disebut Shatibi) yang selalu gelisah melihat kondisi intelektual dan moral umat Islam yang dihadapinya. Oleh karena itu, Shatibi menyusun dua karya besarnya untuk memberikan jawaban alternatif bagi perubahan dan perbaikan kondisi obyektif umat Islam.

Untuk merealisasikan obsesinnya, Shatibi meletakkan pemikiran reformasinya dalam tiga agenda besarnya.

Pertama; melakukan rekontruksi terhadap perumusan maqasid al-shari'ah (tujuan hukum). Rumus konvensional yang didasarkan pada asumsi teologi Ash'ariyah dianggapnya

\footnotetext{
${ }^{6}$ Nama lengkapnya adalah Ali bin Ahmad bin Sa'id bin Hazm. Ia menjuluki dirinya dengan nama Abu Muhammad namun lebih terkenal dengan julukan Ibnu Hazm. Ia sangat produktif dalam karya penulisan hingga karyanya mencapai 131 buah dengan perincian 46 buah buku masih dapat ditemukan dan yang 85 buah sudah tidak dapat ditemukan karena hilang. Lebih jauh bias dilihat dalam buku Ibnu hazm wa Minhajuh fi Dirasah alAdyan oleh Dr. Mahmud Ali Himayah alih bahasa Khlm.id al-Kaf, M.Ag : Ibnu Hazm: biografi, karya dan kajiannya tentang Agama-agama, Jakarta: Lentera, 2001, hlm..83.
} 
tidak mampu menghadapi tantangan zaman dan perubahan social. Padahal sebagaimana dinyatakan oleh sosiolog muslim Abdurrahman Ibn Khaldun, keadaan dunia bangsabangsa,adat-istiadat dan keyakinan mereka tidak selalu mengikuti suatu model dan system yang tetap melainkan berubah. Hal ini sudah menjadi sunnatullah dalam kehidupan umat manusia. Oleh karena itu, bagi Shatibi, asumsi teologi yang menafikan elaborasi maqasid alshari'ah (tujuan hukum) harus digeser dan diganti dengan yang mengakomodasinya. Pendapat ini selaras dengan asumsi teologi Mu'tazillah, maka Shatibi tanpa meninggalkan keterkaitannya secara formal dengan teologi Ash'ari, diam-diam ia mengadopsi pandangan Mu'tazilah. Lebih dari itu pandangan ini sudah dipegangi dan dilakukan oleh para mujtahid cerdas dikalangan sahabat Umar bin Khattab sebagai tokoh utamanya. ${ }^{7}$

Kedua: Konsepsi tradisional qat'i (nas yang pasti) dan zanni (nas yang belum pasti) terlalu sederhana dan tidak memuaskan disamping dasar asumsinya juga lemah. Klasifikasi ini hanya didasarkan pada pemaknaan parsial dan individual dengan logika deduktif dalam memahami teks-teks mas sha'i. Ada dua kelemahan mendasar yang inheren dalam asumsi ini. Secara semiotic selalu terdapat kemungkinan pengertian multi makna sebagai akibat factorfaktor gramatikal dan sintaksis, seperti adannya perbedaan bacaan (qira'ah) kerena perbedaan analisis semantic. Adannya polisemi (al-isytirak) dan lain sebagainya. ${ }^{8}$ Disamping itu, pendekatan ini kurang memberikan tempat kepada kenyataan historis yang melatarbelakangi sehingga teks menjadi tercabut dari konteks yang melatarbelakanginya, padahal ilmu asbab al-nuzul yang dikembangkan dalam tradisi intelektual umat Islam salah satu fungsinya adalah untuk memahami dengan baik konteks suatu nas. ${ }^{9}$

\footnotetext{
${ }^{7}$ Abu Ushaq al-Shatibi, al-Muwafaaqat, Bairut: dar al-Kutub al-Ilmiyyah, t.t., vol. 1, hlm.. 18.

8 I b i d., vol III, hlm.. 13-14.

${ }^{9}$ I b i d., vol IV, hlm.. 47-49.
} 
Oleh karena itu dalam menganalisis suatu nas dalam kaitannya dengan perubahan social mau tidak mau harus mengunakan pendekatan induksi empirik yang melibatkan kajian historis sosiologis dalam pemahaman nas. Induksi yang dimaksud Shatibi ialah upaya pengumpulan dan pengunaan nas yang mempunyai indikasi dukungan makna yang serupa secara bersama-sama. Ini didasarkan pada asumsi bahwa kebersamaan mempunyai kekuatan yang tidak dimiliki oleh kesendirian sehingga seberapa jauh tingkat kepastian suatu nas parallel dengan bukti-bukti yang berhasil dikumpulkan. Semakin banyak bukti nas yang berhasil dikumpulkan semakin tinggi tingkat kepastiannya. Bagitu pula sebaliknya.

Ketiga: Pengembangan konsepsi maslahah mursalah yang khas mazhab Maliki yang ditopang dengan pendekatan ganda, mengikat diri secara proporsional pada pemahaman tekstual dan pencarian tiada henti akan tujuan hukum (maqasid al-shari'ah). Bagi Shatibi, ia memandang shari'ah secara esensial dihubungkan dengn wahyu dan bisa dipertahankan dalam rangka kelansungan dan kebutuhan ijtihad. ${ }^{10}$

Dengan latar belakang yang demikian, maka sangat menarik untuk mengkaji lebih jauh pemikiran Shatibi yang meliputi metodologi hukum Islam yang membentuk konstruk hukumnya.

\section{B. Rumusan Masalah}

Dari paparan latar belakang masalah di atas dapat dirumuskan beberapa pokok masalah, yakni:

1. Bagaimana kerangka pikiran Shatibi dalam memahami tujuan hukum (maqasid alshari'ah) dalam sistem hukum Islam?

\footnotetext{
${ }^{10}$ Khlm.id Mas'ud, Islamic Legal Philosopy: a study of Abu Ishaq al-Shatibi's Life and Thought, diterjemahkan Yudian W Asmin, Filsafat Hukum Islam dan Perubahan Sosial, Surabaya: al-Ikhlas, cet.I, hlm.224.
} 
2. Apa landasan pemikiran Shatibi yang melatarbelakangi konsep-konsepnya tentang tujuan hukum (maqasid al-shari'ah)? Bagaimana kontroversi yang terjadi dalam dinamika pemikiran filsafat hukum Islam dalam kaitannya dengan konsep tujuan hukum?

\section{Tujuan dan Kegunaan Penelitian}

Penelitian ini dimaksud sebagai salah satu upaya untuk mengisi kelangakaan dalam studi yang dikhususkan pada pemikiran Shatibi tentang tujuan hukum (maqasid al-shari'ah) dalam magnum opusnya, al-Muwafaqat. Penelitian ini diharapkan mampu memberikan sedikit sumbangan yang berarti bagi khasanah pemikiran Islam. Selain juga diharapkan mampu menumbuhkan rasa optimisme dalam masa depan kajian Islam.

\section{Pembahasan}

Untuk menelusuri pemikiran Shatibi tentang tujuan hukum (maqasid al-shari'ah) penulis akan merujuk kepada buku utamanya, yaitu: al-Muwafaqat ${ }^{11}$

Buku ini sebagaimana telah dijalaskan merupakan rujukan terpenting dalam mengelaborasikan pemikiran Shatibi tentang tujuan hukum. Dari buku ini akan diketahui bagaimana kerangka pemikiran Shatibi tentang tujuan hukum. Metodologi yang digunakan untuk memahami perbadaan rumusan hukum. Cara membandingkan antara suatu maksud dengan maksud lainnya sekaligus cara menginduksinya.

Penelitian buku Syatiby ini merupakan sumber data primer yang akan digunakan dalam ini. Sedangkan untuk membantunnya akan digunakan juga buku-buku usul fiqh mulai

11 Judul buku ini sesuai dengan apa yang disampaikan oleh Shatibi sendiri dalam pembukaannya, dan juga sebagaimana yang dicatat oleh Zarikhli, Kahhlm.ah dan Brocklemann adalah al-Muwafaqat saja tanpa ada tambahan apa-apa. Anehnya Abdu al-Darras dan Muhammad Khadir Khusain masing-masing menamakannya dengan al-Muwafaqat fi Usul al Shari'ah dan al-Muwafaqat fi Usul al-Ahkam. 
dari yang klasik seperti al-Risalah karya Imam Shafi'i dan lain-lain sampai yang mutakhir seperti usul fiqh al-islam karya Wahdah al-Zuhaily dan lain-lainnya. Doktrin maqasid alshari'ah merupakan kontiuitas dan pengembangan dari konsep maslahah sebagaimana dikembangkan pada masa pra Shafi'i. Shatibi berpendapat bahwa kesatuan hukum Islam berarti kesatuan dalam asal-muasalnya terutama lagi dalam maksudnya. Ia juga menyentuh masalah teologis terutama bagi dalam maksudnya. Ia juga menyentuh masalah teologis dimana kelompok Asy'ariyah tidak sependapat dengannya. Menurut ia Tuhan melembagakan shari'ah demi kebaikan manusia, baik jangka pendek maupun jangka panjang. ${ }^{12}$ Penetapan hukum didasarkan atas pertimbangan sebab atau motif dalam usul fiqh disebut dengan illah (jamak: 'ilal). Hal inilah bagi kelompok Ash'ari tidak sependapt dengannya karena menganggap bahwa perbuatan Tuhan harus punya kebaikan (maslahah) terhadap MakhlukNya sehingga Ia tidak punya kehedak sendiri. Namun kaum Mu'tazilah meyakini bahwa perintah-perintah Tuhan disebabkan oleh maslahah manusia . Kebanyakan fukaha' menerima pendapat yang terakhir ini karena tidak bisa dihindari bahwa illah ditegakkan demi hukum shar'iah.

Shatibi berpendapat bahwa maslahah ditegakkan dalam shari'ah melalui metode induksi sebagai tema umum dalam hukum maupun sebagai deskripsi illah dari berbagai perintah secara rinci. ${ }^{13}$

Perlu dikemukakan juga disini tulisan-tulisan yang pernah di publikasikan sebelumnya tentang pemikiran Shatibi. Sepanjang pengetahuan penulis, publikasi tulisan yang secara khusus membicarakan pemikiran Shatibi secara mendetail adalah Islamic Legal

\footnotetext{
12 Abu Ishaq al-Syatibi, op. cit., juz II, t.th, hlm.2.

${ }^{13}$ I b i d., hlm. 3.
} 
Philosophy, sebuah disertasi yang ditulis olehMuhammad Kholid Mas'ud ${ }^{14}$. Aspek-aspek teologis dalam konsep maslahah menurut Shatibi sebagaimana terdapat dalam al-Muwafaqat juga sebuah disertasi yang ditulis oleh Hamka Haq ${ }^{15}$ dan Konsep Maqasid Shari'ah, sebuah buku yang berasal dari disertasi yang disusun oleh Asafri Jaya Bakri. ${ }^{16}$

Hamka Haq mengungkapkan secara khusus pemikiran Shatibi dalam aspek teologis sebagaimana dipahami dari pandangan-pandangan teologis Shatibi tentang tahsin (kewajiban mengerjakan perbuatan baik) dan taqbih (kewajiban meninggalkan perbuatan jelek) sehingga kurang memuaskan. ${ }^{17}$

Dari penjelasan Haq bila dibandingkan dengan cara Fazlur Rahman terhadap karya Shatibi ini menampilkan perbedaan yang sangat tajam. Disamping itu tentu saja Hamka Haq tidak membicarakan ide-ide Shatibi tentang hukum (shari'ah).

Sementara itu Khalid Mas'ud sekalipun secara khusus menguraikan pandangan filosofis Shatibi dibidang hukum Islam, namun ia tidak mengungkapkan pandangan Shatibi tentang metodologi yang digunakannya untuk merumuskan tujuan hukum. Bakri sebenarnya telah mengarahkan pembahasannya pada tujuan hukum yang mengungkapkan relevansinya dengan serta signifikansinya dalam ijtihad hukum Islam dewasa ini. Hanya saja penjelasannya tidak menyinggung aspek metodologi dalam konsep tujuan hukum. ${ }^{18}$ Padahal

14 Buku ini telah diterjemahkan oleh ke dalam bahasa Indonesia oleh Yudian W. Asmin dengan judul Filsafat Hukum Islam dan Perubahan Sosial, diterbitkan oleh al-Ikhlas, Surabaya, tahun 1995.

${ }^{15}$ Hamka Haq, Aspek-Aspek Teologis dalam Konsep Maslahah menurut al-Syatibi sebagai yang terdapat dalam al-Muwaffagat, Jakarta: Fakultas Pasca Sarjana IAIN Syarif Hidayatullah, 1989.

${ }^{16}$ Asfri Jaya Bakri, Konsep Maqasid Syari’ah Menurut al-Syatibi, Jakarta: Rajawali Press, 1996. hlm.

${ }^{17}$ Tentang arti tahsin dan taqbih lihat al-Bazdawi, Ushul al-Din, Kairo: Isa al-Badi al-Hlm.abi, 1963,

18 Dalam membaca pemikiran Shatibi tentang cara mengetahui maksud-maksud Shari'ah, Bakri hanya mengungkapkan apa yang ditulis oleh Shatibi ketika membicarakan hlm. yang dimaksud, sementara metodologi penting yang membedakan Shatibi dengan yang lainnya tidak dijelaskannya. Metodologi tersebut adalah Istiqra'. Memang metode ini tidak disebut oleh Shatibi dalam pembahasan khusus tentang cara mengetahui maksud shari'ah, namun demikian siapapun yang meneliti Shatibi dengan sungguh-sungguh akan menemukan bahwa metode ini seringkali diungkapkan oleh Shatibi dalam berbagai kesempatan. 
menurut hemat penulis, aspek inilah yang semestinnya dikembangkan untuk meningkatkan peran hukum Islam (Shari'ah) pada dataran percaturan hukum dalam dimensi global.

Perbincangan tentang Shatibi juga telah dilakukan oleh Fazlur Rahman meskipun secara singkat. Dalam bukunya Islamic Methodology in History yang diterbitkan pertama kali pada tahun 1964, Fazlur Rahman menemukan Shatibi sedikit berbeda dengan pemikirpemikir muslim lainnya yang dalam argument-argumentasinya, Rahman melihat suatu penolakan terhadap kekuatan intelektual dan moral manusia. ${ }^{19}$ sungguhpun demikian Rahman enggan membawa kesimpulan di atas kepada pemikir Shatibi secara kategoris menolak bahwa akal mempunyai peran utama dalam membuat hukum atau bahkan dalam

formulasi kewajiban-kewajiban moral, tetapi ia (Shatibi) sendiri telah mengunakan kemampuan rasional untuk mencanangkan tujuan-tujuan shari'ah. ${ }^{20}$ Hanya saja Rahman tidak menjelaskan lebih jauh bagaimana ancaman Shatibi dalam pengunaan daya akal itu untuk menemukan tujuan hukum.

\section{Cara Mengetahui Maqasid al-syaria'ah}

1. Kepastian dan Kemungkinan

Para ulama sudah menegaskan bahwa segala keputusan dan peryataan kita harus berdasarkan pengetahuan sebagaimana firman Allah

(Dan janganlah kamu mengikuti apa yang kamu tidak mempunyai pengetahuan tenatangnya) baik yang bersifat keduniawian maupun lebih-lebih keakhiratan.

Akan tetapi dalam praktek, kita sering dihadapkan pada kenyataan bahwa kita tidak selalu menemukan bukti-bukti yang dapat memberikan kepastian seperti itu. Kita dalam

\footnotetext{
${ }^{19}$ Fazlur Rahman, Islamic Methodology in History, terjemahan Anas Mahyudin, Membuka Pintu Ijtihad, Bandung: Pustaka, 1995, hlm. 205. Lihat juga karya Rahman, Islam and Modernity Transformation of an Intellectual Tradition, terjemah Ahsin Muhammad, Islam dan Modernitas: Tentang Transformasi Intelektual, Bandung: Pustaka, cet.II, 1995, hlm. 23-24.

${ }^{20}$ I b i d., hlm.. 142-143.
} 
banyak hal terpaksa harus merasa puas denga potongan-potongan kecil bukti yang tidak menghasilkan pengetahuan pasti dam konklusi melainkan hanya menghasilkan suatu persepsi hubungan yang tidak sepenuhnya mengambarkan validitas deduktif rasional. Demi alasan pragmatis, prinsip seperti ini diklalangan sebagian besar ulama ushul fikih terpaksa diterima. Sebab kalau tidak diterima akan banyak bagian hukum-hukum agama akan terabaikan. ${ }^{21}$ Akan tetapi walaupun kita dapat merasa puas dengan potongan-potongan bukti yang kecil untuk melakukan istimbat (perumusan) hukum, namun bukti-bukti itu harus sedemikian rupa sehingga pengetahuan hukum yang kita peroleh melaluinya cukup dipertanggungjawabkan dan dibenarkan secara metodologi hukumnya.

Untk mengambarkan apa yang dikemukakan terdahulu para ulama usul mengintrodusir dua konsep penting, yaitu al-ilm (pengetahuan) dan al-zann (asumsi). ${ }^{22}$ Dalam kaitan ini kita sering mendegar istilah dalil yang qat'i dan dalil zanni serta hukum yang qat'i dan hukum yang zanni. Perkataan al-ilm, al-qat', dan al-yaqin adalah kita istilah yang digunakan secara sinonim oleh para ulama ushul fikih. Dalam al-ilm (pengetahuan) dimaksudkan keyakinan yang sesuai dengan kenyataan obyek dan menimbulkan kepastian serta ketenangan jiwa subyek bersangkutan. ${ }^{23}$

Dalam al-ilm terdapat kepastian sedemikian rupa dimana tidak ada tempat bagi keragu-raguan sedikitpun. Sedangkan al-zann (asumsi) adalah dugaan kuat yang mempunyai peluang yang amat besar untuk benar dan kita mempunyai cukup alasan untuk meyakini

\footnotetext{
${ }^{21}$ Ghazali mengutip beberapa orang yang menolak khabar ahad (laporan tunggal) sebagai sumber pengetahuan tentang hukum agama karena tidak menimbulkan kepastian melainkan kemungkinan belaka. AlGhazali, op.cit., vol. I, hlm. 172.

${ }^{22}$ Terjemahan zanny dengan kata asumsi diambil dari Peters, God 'syari'ah Created Speech, Leiden: E. J. Brill, 1976, hlm. 45.

${ }^{23}$ Uraian tentang konsep pengetahuan dikalangan ulama ushul fikih menurut Qadi Abd Jabbar lihat Peters, I b i d., hlm. 40-104; Sedangkan menurut ulama Islam secara umum lihat F. Rozenthlm., Knowlegde Triumphant, Leiden; E. J. Brill, 1970, hlm 71-79.
} 
kebenarannya. Meskipun para ahli ushul fikih membedakan secra tegas antara 'ilm dan zann, namun mereka kadang-kadang menetapkan penamaan zann dengan 'ilm.

Sepanjang yang dapat ditelusuri dengan karya-karya ushul fikih yang ada, adalah Syafi'i orang pertama yang mengagas konsep qat'i dan zanni, walaupun ia belum mempunyai istilah khusus untuk menampung konsep tersebut. Dalam al-Risalah, Syafi'i mengambarkan ide tentang qat'i dan zanni pada dua tempat.

Pertama, ketika menjelaskan pengetahuan hukum yang diperoleh melalui khabar ahad, dan kedua, ketika menjelaskan otoritas qiyas. Ketika menjelaskan otoritas khabar ahad, Syafi'i ditanya apakah pengetahuan yang diperoleh melalui dalil-dalil itu berbeda-beda. Ia mengatakan bahwa dalil yang merupakan khabar ahad yang diriwayatkan melalui jalur tunggal (al-tariq al-infirad) dan mengadung kemungkinan-kemungkinan mengikat bagi semua orang dan tidak boleh ditolak. Akan tetapu dalil tersebut tudak menghasilkan kepastian (ihatah) tentang kebenaran seperti kepastian yang ditimbulkan oleh nas al-Qur'an dan khabar mutawatir.

Kebenaran hukum yang dihasilkan oleh khabar ahad itu bersifat lahir, karena itu orang yang meragukannya tidak sampai keluar dari Islam dan tidak disunnahkan bertoubat. Seperti halnya keputusan hakim yang berdasarkan keterangan seorang saksi kebenarannya hanya lajirnya saja, karena mungkin saja saksi itu bohong. Sedangkan dalil nas yang berupa al-Qur'an yang jelas dan Sunnah yang yang telah disepakati menimbulkan kepastian (ihatah) dan barang siapa mengingkarinya berarti keluar dari agama Islam dan ia harus bertaubat untuk dapat menjadi muslim kembali. ${ }^{24}$ Pada tempat lain ketika menjelaskan apakah orang yang melakukan qiyas (analogi) yakin dan pasti bahwa mereka dapat memperoleh kebenaran yang sesungguhnya mengenai hukum yang dikendaki Allah, Syafi'i mengatakan bahwa

\footnotetext{
${ }^{24}$ Al-Syafi'i, I b i d, al-Risalah, Kairo: Maktabah Dar al-Turas, 1979, hlm. 460-461.
}

\section{Jurnal Gema Keadilan}


kebenaran itu ada yang bersifat lahir dan batin, dan ada yang hanya merupakan kebenaran pada lahirnya saja, yaitu sepanjang dapat kita buktikan. Dalil yang diriwayatkan berupa nas al-Qur'an dan Sunnah Rasul yang diriwayatkan secara mutawatir menghasilkan kebenaran yang lahir dan batin, sedangkan dalil yang berupa khabar ahad melahirkan kebenaran pada lahirnya saja seperti kebenaran yang disimpulkan hakim berdasarkan keterangan para saksi yang mungkin saja berbohong. Termasuk kebenaran pada lahirnya yaitu sepanjang yang dapat kita capai dengan bukti kongkrit yang ada adalah kebenaran yang dihasilkan oleh qiyas. $^{25}$

Dikalangan ulama ushul fikih yang dating kemudian barulah Syatibi yang melakukan rekonstruksi pemahaman qat'i dan zanni. Sebelumnya dikalangan mereka pemahaman qat'i dan zanni tidak banyak berbeda dengan pengertian sebagaimana dikemukakan di atas. Dalam hal ini seriing ditemukan ungkapan "khabar mutawatir menimbulkan kepastian", seperti disinggung terdahulu, adalah al'ilm, al-yaqin dan al-qat'." Disamping itu ulama juga mengatakan "khabar ahad yang menimbulkan zanni (dugaan kuat)."26 Kutipan ini menunjukkan bahwa qat'I dan zanni digunakan untuk menjelaskan otoritas dalil-dalil untuk melandasi pengetahuan ditinjau dari segi asal-usul histori dalil-dalil itu (wurud). Memang demikianlah pengertian yang selalu dipakai dalam karya-karya klasik ushul fikih.

Perbedaan pengetahuan hukum menjadi qat'i dan zanni sebenarnya bukanlah perbedaan kategoris, melainkan lebih merupakan penjenjangan tingkat-tingkat kepastian dan probabilitas dalam pengetahuan itu. Sejauh mana kepastian kita tentang suatu hukum syari' yang diistimbatkan sangat tergantung kepada sejauh manan kita berhasil mengumpulkan potonga-potongan bukti (dalil) yang memberikan dukungan atau konfirmasi kepada hukum

\footnotetext{
${ }^{25}$ I b i d., hlm. 477-483.

${ }^{26}$ Ghazali, al-Mustasfa, vol. I, hlm. 146; Syaukani, op.cit., hlm. 48.
} 
bersangkutan. Ini mengingatkan kita kepada semacam pengetian tentang kolaborasi indulsi yang mana bukti tidak menelorkan konklusi yang pasti dalam pengertian argument deduktif, melainkan lebih memberikan dukungan dan penguatan terhadapnya atau dengan kata lain kebenaran premis tidak menghasilkan kebenaran konklusi secara demonstrasi, tapi memberikan alasan yang cukup untuk mempercayainya. ${ }^{27}$

Pengertian kolaborasi induktif ini memainkan peranan yang cukup bebarti dalam elaborasi banyak konsep-konsep penting dalam teori hukum Islam. Apabila penegasan pengertian ini kita dapatkan dalam karya-karya mengenai teori hukum Islam, maka tidak ada yang lebih jelas dari penegasan Syatibi. Menurut Syatibi dalil-dalil syari’ harus digunakan secara bersama-sama apabila dikehendaki suatu tingkatan kepastian lebih tinggi dalam kesimpulan. Qat'i dalam masing-masing dalil secara individual tidak ada atau amat langka. Apabila dalil-dalil ini berupa khabar ahad, maka kesimpulan yang dihasilkan berbentuk zanni. Adanya beberapa kemungkinan hisrotis, misalnya telah dinasakh oleh dalil lain. Oleh perbedaan analisis sintaksis, adanya polisemi (al-isytirak; makna ganda) dan banyak hal lainnya. $^{28}$

Sifat qat'i lahir dari pengunaan dalil-dalil secara bersama-sama. Dari gabungan dalildalil itulah ditarik secara deduktif suatu kesimpulan dimana dalil-dalil tersebut saling berkorobosi mendukung kesimpulan itu sehingga dapat diperoleh suatu kepastian. Kebenaran mengandung kekuatan yang tidak terdapat dalam kesendirian. Pola argumentasi yang disarankan disini terasuk dalam termasuk dalam kategori demikianjadi apabila dari kumpulan sejumlah bukti (dalil) ditarik secara induktif suatu kesimpulan yang memebrikan kepastian, maka itulah model argumentasi yang kita inginkan. Kepastiannya adalah sedemikian rupa

\footnotetext{
${ }^{27}$ Wael B. Hlm.laq “Inductive Corroboration, Probability and Certainly”, dalam Nicholas Heer, (ed), Islamic Law and Jurisprudence, Seattle and London: University of Washington Press, 1990, hlm. 7-8.

${ }^{28}$ Syatibi, op.cit., hlm. 13-14.
} 
seperti kepastian kita tentang keberanian Ali Ibn Abi Talib dan kedermawanan Hatim yang kita peroleh dari banyak kasus yang dilaporkan tentang kedua orang itu. Rukun Islam yang lima itu qat'i dan qat'inya diperoleh dengan cara demikian itu. Kepastian kita tentang wajibnya shalat fardu yang lima, umpamanya, tidak semata-mata ditunjukkan firman Allah "dan dirikanlah shalat...." dan apabila orang yang berargumentasi atas wajibnya shalat dengan semata-mata ayat tersebut argumentasinya akan mengadung kekurangan dari beberapa segi. Kita mengetahui wajibnya adalah dari kebersamaan firman tersebut dengan sejumlah bukti lain yang saling berkorobosi untuk mendukung pemaknaan perintah (amr) dalam firman Allah tersebut sebagai menunjukkan waajib. Misalnya kita menemukan pujian terhadap orang yang mengerjakan shalat, celaan terhadap orang yang meninggalkannya, adanya perintah untuk mengerjakannya dalam keadaan duduk tidak mampu berdiri, bahkan berbaring apabila tidak bisa duduk dan sejumlah bukti lain. Kebenaran dalil-dalil ini yang menhasilkan kepastian kepada kita atas wajibnya shalat.

Prinsip kebersamaan seperti dikemukakan terdahulu tidak selalu dipahami dalam arti formal, yaitu dilekatkan pada ekspresi verbal formal yang terkandung dalam teks-teks alQur'an atau sunnah. Akan tetapi dikaitkan dengan makna dan substansi bersama yang meresapi keseluruhan sumber material syari'ah. Induksi dalam teori ini bukanlah sejumlah besar laporan yang dikaitkan pada suatu isu pertikular, melainkan suatu induksi tematik (istiqra' maknawi) dari semangat dan urf syari'ah. Dalil yang terlibat mungkin tidak semuanya langsung secara khusus melandasi kasus khusus atau bahkan tidak meyentuh permasalahan yang dibicarakan. Hanya saja hubungannya tidak langsung dan dukungan subsidenya terhadap masalah tersebut membawa kepada suatu kepastian dan keyakinan tentang kebenaran hukum yang disimpulkan. Syatibi menjelaskan "apa yang mengandung pengulangan, penekanan dan tema yang sama serta dikuatkan oleh berbagai indikasi luar

\section{Jurnal Gema Keadilan}


menjadi setingkat dengan nas qat'i yang tidak mengandung kemungkinan-kemungkinan interpretasi lain. $^{29}$

Jadi dengan demikian adalah keberulangan makna dan tema dalam teks dan konteks yang membawa kepada kepastian pada kita, bukan semata-mata analisis teks secara individual. Analisi teks murni bahkan tidak akan pernah membawa kepada kepastian. Ajakan yang kuat dari Syatibi untuk melakukan analisis teks dengan pendekatan induktif mengimplikasikan seruanya untuk mengembangkan pola piker induktif secara luas. Pola piker semacam ini sekarang semakin dirasakan urgensinya karena pemikiran model induktif diyakini akan membawa kepada kemajuan.

\section{Pendekatan tengah antara Dua Ekrtrim}

Dalam pembahasan terdahulu telah dikemukakan dua aliran dalam sejarah Islam yang apabila ditarik garisnya akan melahirkan dua teori yang paradoksal; subyektivisme teistik dan obyektivisme rasionalistik. ${ }^{30}$ Hanya saja dalam kenyataaan para penganut teori obyektivisme rasionalistik belum mampu melahirkan mazhab hukum tersendiri sehingga dalam pamikiran hukum mengikuti teori-teori hukum yang dikembangkan oleh pemikir dari kalangan subyektivisme teistik (baca Asy'ariyah). Bukti paling jelas adalah Qadi Abd Al-Jabbar pemikir besar obyektivisme rasionalistik (baca Mu’tazilah), yang ternyata mengikuti mazhab Syafi'i dalam bidang hukum.

${ }^{29} \mathrm{I}$ b i d., vol. III. 174.

${ }^{30}$ Nama inin diberikan oleh George F. Hourani dalam karyannya Islamic Rtionalism, Oxford: Clarendoon Press, 1971, hlm. 3, 10 dan 12. Menurut teori yang pertama hukunhanya dapat dikenali melalui wahyu ilahi yang dibakukan dalam kata-kata yang dilaporkan dari Nabi berupa al-Qur'an dan sunnahnya. Katakata tersebut merupakan sumber pokokhukum dan disebut dalil. Analisis hukum pada gilirannya hanya terfokus pada analisi teks-teks suci itu. Waji, haram, baik, buruk dan seterusnya hanya dapat diketahui melalui sumbersumber tersebut.

Sementara itu menurut teori obyektivisme hukum dapat dikenal oleh akal tanpa bantuan wahyu, Hukum bersifat obyektif dan telah tertanam sebagai bagian dalam susunan alam. Demi keadilannya Tuhan tidak menghendali keburukan, karena itu Dia menaganjurkan yang maslahah. Ilmu hukum golongan ini diarahkan pada analisis kenyataan historis untukmenemukan tonggak dasar hukum yaitu maslahah dan mafsadah. Wajib, haram, dan kategori hukum yang lain dapat diketahui dengan pertimbangan segi-segi maslahah dan mafsadah dalam perbuatan manusia. Pandangan ini merupakan pemikiran Mu’tazilah. 
Dalam kaitan ini Syatibi bisa disebut sebagai tokoh yang selalu berupaya mencari jalan tengah diantara polaborasi pemikiran di atas. Misalnya saja ketika mengemukakan prmis teologis untuk memberikan landasan yang kokoh bagi hasil penelitiannya yang menyimpulkan bahwa ayari'ah semata-mata ditetapkan untuk kemaslahatan manusia (konsep ta'lil isa dikatakan ia Mu'tazilah), Syatibi segera menyusulinya dengan mengatakan bahwa tidak ada tahsin dan taqbih (akal tidak mutlak mengetahui apa yang baik dan pa yang buruk).

Syatibi juga melihat perlunya menyeimbang antara analisi teks dan analisis realitas masyarakat dalam penalaran dan argumentasi hukum. Syatibi menjelaskan bahwa ijtihad hukum bergerak dalam dua arah menuju ke titik yang sama. Arah pertama merupakan analisis tekstual untuk menemukan inti dan illat hukum. Arah kedua melakukan analisis terhadap kasus untuk menemukan inti permasalahan yang sebenarnya. ${ }^{31}$ pada bagian lain ia menyarankan apa yang sekarang kita sebut pendekatan sosio historis, yaitu mempelajari teks yang berasal dari suatu sumber bersejarah di lafalkan secara tercabut dari konteksnya, sehingga pemahaman teks itu semata-mata berdasarkan teks itu sendiri bisa menyesatkan. Karena itu analisis historis terhadap konteks yang dilahirkan mutlak diperlukan. ${ }^{32}$

Dari apa yang dikemukakan di atas secara keseluruhan kita dapat mengambil garis besar metodologi ijtihad yang ditawarkan Syatibi. Pilar untuma ijtihad terletak pada unsure sebagaimana telah disinggung dalam pendahuluan tesis ini, yaitu analisi teks dan elaborasi maqasid al-syari'ah ${ }^{33}$ dengan demikian metodologi yang dimaksudkan oleh Syatibi ialah pola penalaran dan argumentasi hukum yang bergerak dalam dua level. Pertama, analisis teks dengan mengunakan pendekatan induktif (istiqra' ma;nawi) yakni mengumpulkan sebanyak mungkin data-data tekstual yang mempunyai makna yang relative sama untuk ditarik makna

\footnotetext{
${ }^{31}$ Syatibi, op.cit., vol. IV, hlm. 47-49.

${ }^{32}$ I b i d., vol III, hlm. 201.

${ }^{33}$ Lihat penyataan Abd. Darraz ketika mengomentari kitab al-Muwafaqatnya Syatibi.
} 
sentral yang dikandungnya. Upaya ini dilakukan untuk menemukann cita hukum syar'I yang ideal. Kedua, melakukan analisi terhadap sosio histori realitas masyarakat untuk menemukan inti persoalan yang sebenarnya. Hal ini dilakukan untuk menemukan relevansi antara cita hukum yang ideal tersebut dengan makna dan maslahah yang sangat terkait dengan historisitas umat manusia. Kedua level analisis ini mungkin akan memperlihatkan adannya jarak tertentu antara hukum ideal sebagai tertuang dalam teks dengan kenyataan masyarakat dan perkembangan social taua tidak. Jika memang terdapat jarak yang unreasonable maka dilakukan usaha pendekatan antara keduanya dengan menyesuaikan hukum ideal tadi sampai batas tertentu dengan perkembangan masyarakat dan keligus melakukan social engineering terhadap masyarakat sesuai dengan tuntutan yang dikendaki oleh kuhun syari’i.

\section{E. Kesimpulan}

Teori maqasid al-syari'ah Syatibi dibangun di atas premis yang sangat meyakinkan bahwa semua hukum syari'ah ditetapkan dengan satu tujuan. Syari'ah deberlakukan bukan untuk dirinya sendiri tetapi "mengabdi" untuk kepentingan diluar dirinya yaitu kemaslahatan manusia. Kemaslahatan manusia paling pokok dan bersifat universal yang menjadi tujuan utama ditetapkan syari'ah adalah kebebasan baragama, keselamatan jiwa, keselamatan akal (intelek), kehormatan keluarga dan keamanan harta benda. Konsepsi Syatibi ini didasarkan pada hasil penelitiannya terhadap nas-nas dan tradisi Syari’ dalam menetapkan hukum. Dari pengamatannya yang mendalam terhadap nas-nas syari'ah, Syatibi sampai pada suatu kesimpulan yang sangat meyakinkan bahwa syari'ah ditetapkan dengan landasan ta'lil maslahi (mempunyai tujuan untuk kemaslahatan).

Metodologi pendekatan ijtihad hukum yang disarankan Syatibi adalah pertama, melakukan istiqra' ma'nawi (kolaborasi induktif) atau induksi tematik terhadap teks-teks nas.

\section{Jurnal Gema Keadilan}


Yaitu suatu metode berpikir yang tidak semata berpijak pada pemahaman individual terhadap suatu nas (cara berpikir deduktif rasinal), akan tetapi lebih mengutamakan pada menulusuran dan inventarisasi nas-nas yang mempunyai tema dan makna yang saling mendukung (kolaboratif). Inventarisasi nas itu dilakukan sampai pada suatu tingkat yang sedemikian rupa sehingga secara akumulatif makna sentral dari nas-nas itu mencapai derajat meyakinkan (qat'i). Seandainya kita tidak berhasil mengumpulkan bukti-bukti (dalil-dalil) sampai pada tingkat yang mencapai kepastian maka kesimpulan yang didapat hanya mengimplikasikan kemungkinan (zanni). Dan kedua, melakukan elaborasi terhadap maqasid al-syari'ah dengan cara berimbang bertumpu pada pendekatan tekstual dan analisis sosio historis. Pendekatan istiqra' ma'nawi mengindikasikan bahwa analisis terhadap nas tidak cukum dengan pendekatan sintaksis semata akan tetapi lebih ditekankan pada upaya pengumpulan buktibukti tekstual yang mempunyai makna dan tema yang sama. Sementara itu dalam elaboraasi maqasid al-syari'ah, dilakukan dengan mengunakan pendekatan tekstual dan analisi terhadap kondisi sosio historis masyarakat dimana nas itu lahir. Pendekatan ini sangat penting untuk melihat nas secara arfi sesuai dengan tuntutan perkembangan masnyarakat. 


\section{F. Daftar Pustaka}

Abu Ishaq al-Shatibi, al-Muwafaqat, Bairut: dar al-Kutub al-Ilmiyyah, t.t., vol. 1

Ahmad Amin, Fajr al-Islam, Kairo: Maktabah al-Nahdiah al-Misriyah, 1975

Al-Syafi'i,al-Risalah, Kairo: Maktabah Dar al-Turas, 1979

Asfri Jaya Bakri, Konsep Maqasid Syari'ah Menurut al-Syatibi, Jakarta: Rajawali Press, 1996.

F.Rozenthlm, Knowlegde Triumphant, Leiden; E. J. Brill, 1970.

Fazlur Rahman, Islamic Methodology in History, terjemahan Anas Mahyudin, Membuka Pintu Ijtihad, Bandung: Pustaka, 1995

George F. Hourani dalam karyannya Islamic Rtionalism, Oxford: Clarendoon Press, 1971

Hamka Haq, Aspek-Aspek Teologis dalam Konsep Maslahah menurut al-Syatibi, Jakarta: Fakultas Pasca Sarjana IAIN Syarif Hidayatullah, 1989.

Khalim al-Kaf, M.Ag : Ibnu Hazm: biografi, karya dan kajiannya tentang Agama-agama, Jakarta: Lentera, 2001.

Khalid Mas'ud, Islamic Legal Philosopy: a study of Abu Ishaq al-Shatibi's Life and Thought, diterjemahkan Yudian W Asmin, Filsafat Hukum Islam dan Perubahan Sosial, Surabaya: al-Ikhlas, cet.I

Rahman, Islam and Modernity Transformation of an Intellectual Tradition, terjemah Ahsin Muhammad, Islam dan Modernitas: Tentang Transformasi Intelektual, Bandung: Pustaka, cet.II, 1995

Sayyib Qutb, al-Muslimin, Kairo: Dar al Misriyyah, t.t., alih bahasa Mu'ti Nurdin, Masyarakat Islam, Jakarta Rajawali Press, 1985

Shahratsani, al-Milal wa al-Mihal, Bairut;Dar al-Fikr, t.t.

Wael B. Hlm.laq “ Inductive Corroboration, Probability and Certainly”, dalam Nicholas Heer, (ed), Islamic Law and Jurisprudence, Seattle and London: University of Washington Press, 1990 